\title{
Functionalization of crown ethers: an approach to the enzyme model for peptide synthesis
}

\author{
Kenj1 Koga and Shigeki Sasaki \\ Faculty of Pharmaceutical Sciences, University of Tokyo \\ Hongo, Bunkyo-ku, Tokyo 113, Japan
}

\begin{abstract}
Chiral crown ethers having two thiol groups were designed and synthesized as an approach to the enzyme model for peptide synthesis. The strategy of the present method consists of four fundamental steps as shown in Scheme II, i.e., (1) mono-ester formation by intracomplex thiolysis followed by protection of the amino group (6 to 10), (2) di-ester formation by intracomplex thiolysis ( 10 to 13 ), (3) peptide bond formation by intramolecular aminolysis with regeneration of one free thiol group (13 to 15 ), and (4) elongation of peptide chain by repeating the above steps (2) and ( 3 ). Synthesis of tri- and tetra-peptide derivatives by this method is descirbed.
\end{abstract}

\section{INTRODUCTION}

Complexation is known to play an essential role in enzyme-catalyzed reactions. Formation of molecular complexes between hosts and guests has been achieved in several artificial systems (ref. 1), and successfully applied to enzyme models in the sense that host-guest complexes are formed prior to the reaction. However, only a limited number of such enzyme models have been reported for bimolecular synthetic reactions (ref. 2). We designed functionalized crown ethers as the enzyme model for the synthesis of peptides based on the general concept of enzyme catalysis (ref. 3 ), in which the reactive enzyme-substrate covalent intermediate $\left(E-S_{1}\right)$ is formed from the noncovalent complex (E---S, ), and then reacts with the second substrate $\left(S_{2}\right)$ to give the product $\left(S_{1}-S_{2}\right)$ as shown in the following equation.

$$
\mathrm{E}+\mathrm{s}_{1} \rightleftharpoons \mathrm{E}---\mathrm{s}_{1} \longrightarrow \mathrm{E}_{1} \mathrm{~s}_{1} \stackrel{\mathrm{s}_{2}}{\mathrm{E}}+\mathrm{s}_{1}-\mathrm{s}_{2}
$$

\section{DESIGN OF THE METHOD}

In 1976, Cram reported a pioneering work on the intracomplex thiolysis of $\alpha$-amino acid pnitrophenyl ester salts with a thiol-bearing chiral crown ether (1) as a mimic of thiolproteases (ref. 4). Lehn reported intracomplex thiolysis of dipeptide p-nitrophenyl ester salts with a chiral crown ether (2) having cysteinyl residues (ref. 5). We also reported intracomplex thiolysis of $\alpha-, \beta-$, and $\gamma$-amino acid $p$-nitrophenyl ester salts with a chiral crown ether (3) having thiol groups as shown in Scheme I (ref. 6). Complex (4) is expected to be formed between 3 and a-amino acid ester salt, and then intracomplex thiolysis occurs to give the corresponding thio-ester (5) with the liberation of p-nitrophenol. This thiolysis reaction was found to be enhanced, because two reaction sites are forced to be assembled in proximity by complexation. It may be reasonable to assume, therefore, that the reaction

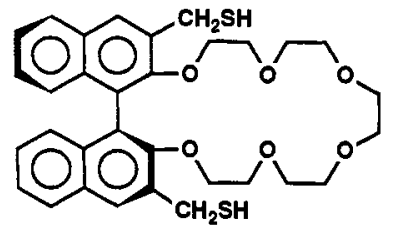

1

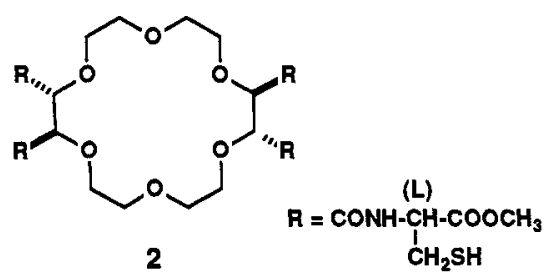

Scheme I<smiles>OCCOCCOCCOCCOC(CS)CS</smiles>

3

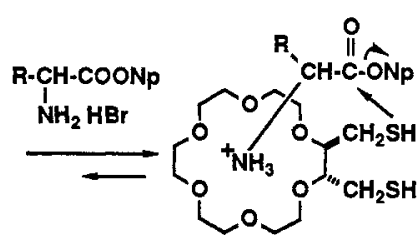

4

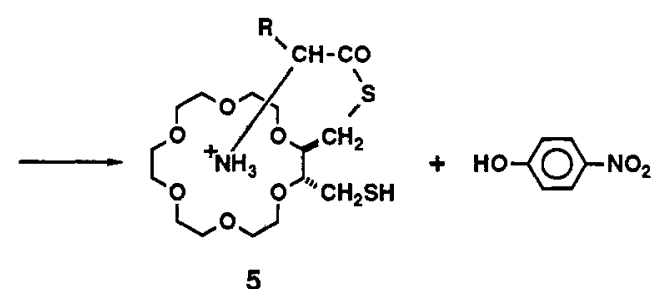


Scheme II

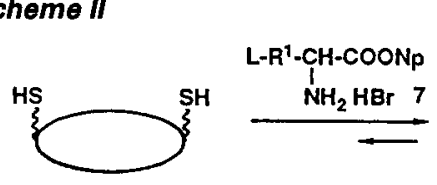

6

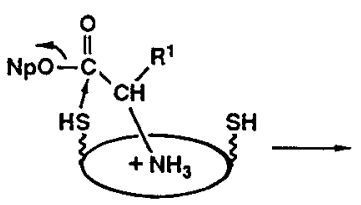

8
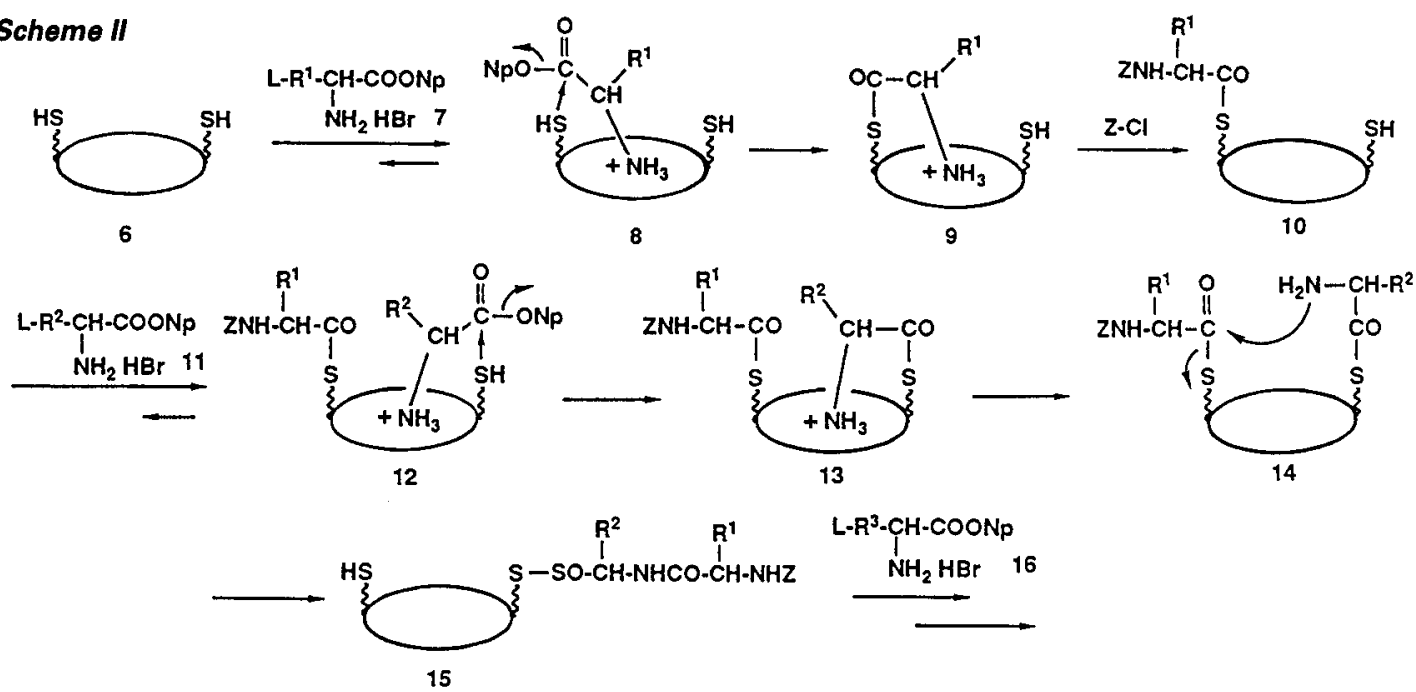

of this thio-ester with nucleophiles will be again enhanced by forcing nucleophiles come close to this ester group. Based on this consideration, crown ether (6) having two thiol groups was designed as an enzyme model for the synthesis of peptides as shown in Scheme II (ref.7, 8). The method consists of the following four steps.

Step 1: Crown ether (6) forms a complex (8) with a-amino acid p-nitrophenyl ester salt (7). Intracomplex thiolysis gives the corresponding thio-ester (9), which 1s converted to 10 having one free thiol and one thio-ester with $\mathrm{N}$-protected $\alpha$-amino acid.

Step 2: Crown ether (10) forms a complex (12) with another $\alpha$-amino acid p-nitrophenyl ester salt (11), and is converted by intracomplex thiolysis to 13, having one thio-ester with $\alpha$-amino acid and one thio-ester with $\mathrm{N}$-protected $\alpha$-amino acid.

Step 3: Intramolecular aminolysis of 13 via a free amine (14) forms a peptide bond (ref. 9) to give 15, which has one free thiol and one thio-ester with N-protected dipeptide. It should be noted that 15 is functionally equivalent to 10.

Step 4: Repetition of the above steps 2 and 3 elongates the peptide chain.

Crown ethers $(3,17-23)$ examined in the present study were synthesized in optically pure forms starting from $\mathrm{L}-(+)$-tartaric acid.

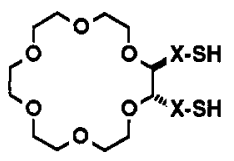

$17: \mathrm{X}=\mathrm{CH}_{2} \mathrm{OCH}_{2} \mathrm{CH}_{2}$ $18: \mathrm{X}=\mathrm{CH}_{2} \mathrm{OCH}_{2} \mathrm{CH}_{2} \mathrm{OCH}_{2} \mathrm{CH}_{2}$

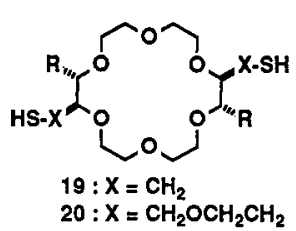

$20: X=\mathrm{CH}_{2} \mathrm{OCH}_{2} \mathrm{CH}_{2}$

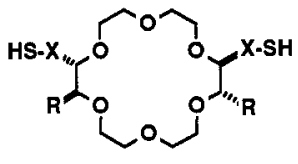

$21: X=\mathrm{CH}_{2}$ $22: \mathrm{X}=\mathrm{CH}_{2} \mathrm{OCH}_{2} \mathrm{CH}_{2}$<smiles>[R]C(C)C(COCCOCCOCCOCCS)OCCS</smiles>

23

\section{INTRACOMPLEX THIOLYSIS}

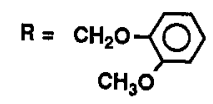

Rate enhancement in thiolysis by thiol-bearing crown ethers is expected from the previous papers (ref. 4, 5, 6). As shown in Scheme III, mono-ester formation was effectively performed for all crown ethers $(3,17-23)$ by intracomplex thiolysis with 7 in weakly acldic buffer solution $(\mathrm{pH}=5.0)$ to give 9, which was treated with carbobenzoxy chloride to 10 . Treatment of 10 with an another amino acid ester salt (11) in pyridine afforded the desired di-ester (13).

\section{Scheme III}

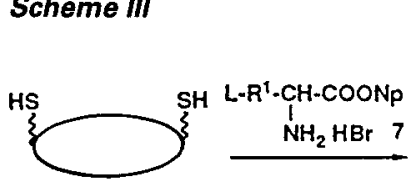

6

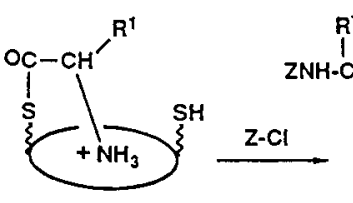

9
$\mathbf{R}^{1}$ I $\mathrm{NH}-\mathrm{CH}-\mathrm{CO}$

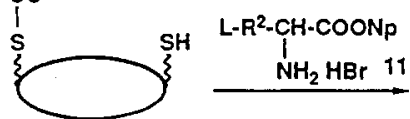

10

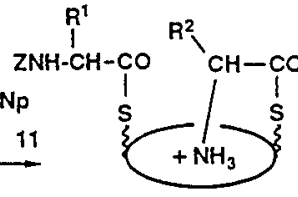

13 


\section{INTRAMOLECULAR AMINOLYSIS}

Aminolysis reaction was first examined with model compounds as shown in Scheme IV. It was shown that intermolecular aminolysis of 24 with 25 was performed most effectively in the presence of acid and base. Under the same condition, 27 did not give the desired Intramolecular aminolysis product (28), probably because the intermediate for 28 is 10 -membered. On the other hand, 29 gave the desired product ( 30$)$.

\section{Scheme IV}

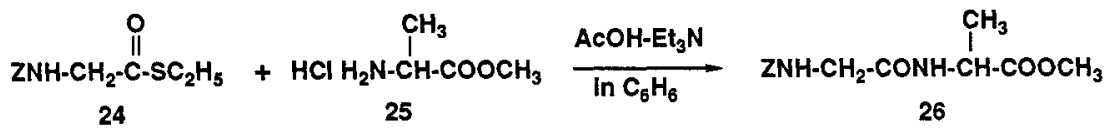<smiles>NCC(=O)SCC(=O)ONCC1CCCC[C@@H]1CN</smiles>

27<smiles>[R]NCC(=O)NCC(=O)SSC[C@H]1CCCC[C@H]1CS</smiles>

28

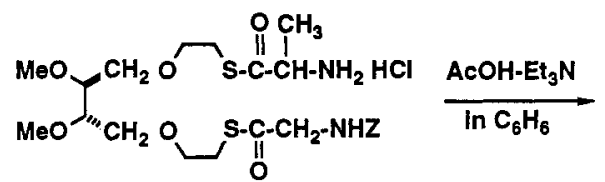

29<smiles>[R]NCC(=O)NC(C)C(=O)SCCOC[C@H](COCCCS)C(OC)OC</smiles>

30

Superiority of intramolecular reaction over intermolecular reaction is clear from Fig. 1 . Thus, intramolecular aminolysis of 29 to give 30 is almost complete within $20 \mathrm{hr}$, while less than $10 \%$ of 26 was formed from 24 and 25 under the same condition shown. Although the intermediate for 30 is 16 -membered, the actual concentration of the nucleophile was calculated to be increased to some 30 times for this intramolecular reaction.

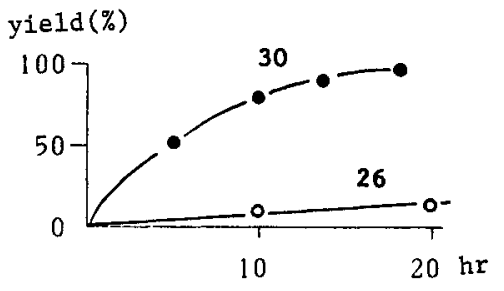

Fig. 1. Comparison of the chemical yields of 26 and 30 In benzene in the presence of $5 \mathrm{mM}$ each of pivalic acid and triethylamine at $20 \pm 1^{\circ} \mathrm{C} . \quad[24]=[25]=[29]$ $=5 \times 10^{-3} \mathrm{M}$.

Based on these data, di-esters (31) were prepared from crown ethers (3, 17-22) as described above, and their intramolecular aminolysis reactions to give dipeptide esters (32) were examined as shown in Scheme $V$. The results are summarized in Table 1 . It is interesting to note that di-ester (31) prepared from crown ether (19) having two thiol groups on the same side in its formula gave the desired product (32) in the absence and in the presence of NaSCN, while di-ester (31) from the crown ether (21) having two thiol groups on the opposite side in its formula gave the desired product (32) in the absence of NaSCN, but did not give any 32 in the presence of NaSCN. It is concelvable that the conformation of the crown ring is disorganized in the absence of the guest to allow two reaction sites come in proximity as shown in 33, but is fixed in the presence of the guest as shown in 34 and 35 . This result may be useful for the design of on-off switch in this reaction.

\section{Scheme V}

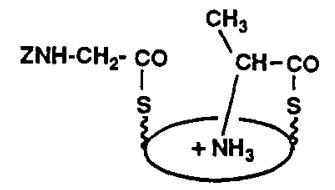

31

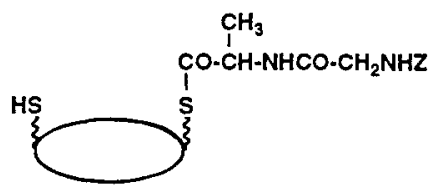

32 
TABLE 1. Intramolecular aminolysis of $31^{\text {a) }}$

\begin{tabular}{cccc}
\hline Run & $\begin{array}{c}\text { Parent crown } \\
\text { ether }\end{array}$ & Time $(\mathrm{hr})^{\mathrm{b})}$ & $\begin{array}{c}\text { Isolated yield(\%) } \\
\text { of } 32\end{array}$ \\
\hline 1 & 3 & - & 0 \\
2 & 17 & 20 & 68 \\
3 & 18 & 10 & 81 \\
4 & 19 & 8.5 & 61 \\
$5^{c)}$ & 19 & 6 & 70 \\
6 & 20 & 3 & 68 \\
7 & 21 & 6.5 & 94 \\
$8^{c)}$ & 21 & - & 0 \\
9 & 22 & 6 & 75 \\
10 & 23 & $>10$ & 73 \\
\hline
\end{tabular}

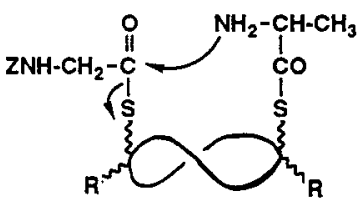

33

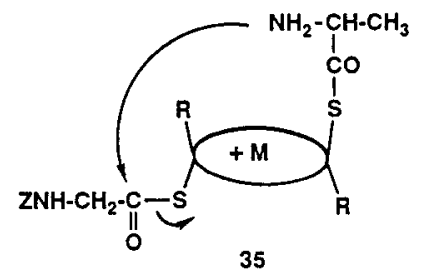

a) In benzene at room temperature. $[31]=5 \times 10^{-3} \mathrm{M}$.

$[t-B u C O O H]=[\mathrm{TEA}]=1.5 \times 10^{-1} \mathrm{M}$.

b) Time required for the disappearance of 31

c) In the presence of $\mathrm{NaSCN}$ ( 3 equivalents to 31 ).

\section{SYNTHESIS OF TRI- AND TETRA-PEPTIDE DERIVATIVES}

Elongation of the peptide chain was achieved by repeating intracomplex thiolysis and intramolecular aminolysis as shown in Scheme VI.

Similarly, by using 38b and L-alanine p-nitrophenyl ester salt, tetrapeptide derivative (Z-Gly-L-Ala-L-Leu-L-Ala-S-crown ether) was also prepared in $60 \%$ 1solated yield.

For the isolation of peptides as their $\mathrm{N}$-carbobenzoxy methyl esters, preliminary examinations were made on the methanolysis of thio-esters as shown in Scheme VII and Table 2. By using an optically pure model compound (39), it is shown that some epimerization at the

\section{Scheme VI}
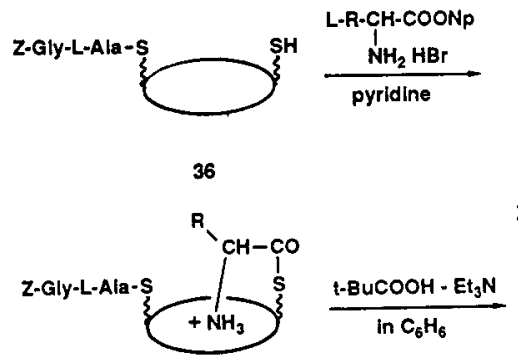

37
Z-Gly-L-Ala-NH-CH-R

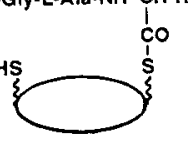

38

Chemlcal yield(\%)

$\begin{array}{ccccc}\text { a } & & & 37 & 38 \\ \text { a } & 18 & \mathrm{CH}_{3}(\mathrm{~L}-\mathrm{Ala}) & 76 & 59 \\ \text { b } & 18 & \left(\mathrm{CH}_{3}\right)_{2} \mathrm{CHCH}_{2}(\mathrm{~L}-\mathrm{Leu}) & 87 & 77 \\ \text { c } & 18 & \mathrm{C}_{6} \mathrm{H}_{5} \mathrm{CH}_{2}(\mathrm{~L}-\mathrm{Phe}) & 92 & 60 \\ \text { d } & 20 & \mathrm{CH}_{3}(\mathrm{~L}-\mathrm{Ala}) & 87 & 81 \\ \text { e } & 21 & \left(\mathrm{CH}_{3}\right)_{2} \mathrm{CHCH}_{2}(\mathrm{~L}-\mathrm{Leu}) & 82 & 74 \\ \text { f } & 22 & \mathrm{CH}_{3}(\mathrm{~L}-\mathrm{Ala}) & 60 & 58\end{array}$

\section{Scheme VII}

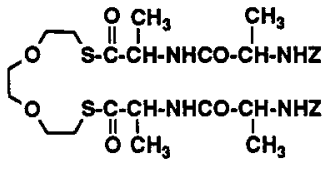

39

$38 \mathrm{~b}, \mathrm{e}$ Z-Gly-L-Ala-L-Leu-OMe 
TABLE 2. Methanolysis of thio-esters ${ }^{a)}$

\begin{tabular}{lcllccc}
\hline Run & Thio-ester & Base(eq.) & Time & Product & Chem. yield(\%) & Diastereomeric ratio $b^{b}$ \\
\hline 1 & 39 & $\mathrm{CH}_{3} \mathrm{OK}(1.0)$ & $3 \mathrm{~min}$ & 40 & $80.5: 19.5$ \\
2 & 39 & $\mathrm{~K}_{2} \mathrm{CO}_{3}(1.2)$ & $30 \mathrm{~min}$ & 40 & $92.5: 7.5$ \\
3 & 39 & $\mathrm{Na}_{2} \mathrm{CO}_{3}(1.2)$ & $2 \mathrm{hr}$ & 40 & $98.5: 1.5$ \\
4 & $38 \mathrm{~b}$ & $\mathrm{~K}_{2} \mathrm{CO}_{3}(2.0)$ & $1 \mathrm{hr}$ & 41 & 86 & $91: 9$ \\
5 & $38 \mathrm{e}$ & $\mathrm{Na}_{2} \mathrm{CO}_{3}(2.0)$ & $2 \mathrm{hr}$ & 41 & 44 & $98: 2$ \\
\hline
\end{tabular}

a) In methanol at room temperature. b) Determined by HPLC.

C-terminal amino acid residue occurs, and that the degree of epimerization is depending upon the conditions employed. Comparing the diastereomeric ratios of the methanolysis products of 39 and $38 \mathrm{~b}, e$, it may be concluded that racemization is quite small during intracomplex thiolysis and intramolecular aminolysis in the present peptide synthesis.

Based on these data, tripeptide derivative (Z-Gly-L-Ala-L-Leu-OMe) and tetrapeptide derivative (Z-Gly-L-Ala-L-Leu-L-Ala-OMe) were obtained after methanolysis followed by purification by column chromatography.

\section{CONCLUSION}

Peptide bond formation by intracomplex thiolysis followed by intramolecular aminolysis and peptide chain elongation by repeating the above two processes have been realized by crown ethers having two thiol groups. These crown ethers have characteristics as an enzyme model for bimolecular synthetic reactions in that they have a single bninding site (18-crown-6 moiety for primary ammonium and metal cations) and two reaction sites (two thiol groups for two substrates) and are used repeatedly for elongation of peptide chain by regenerating one thiol group in each cycle.

\section{Acknowledgements}

The authors express their sincere appreciation to their coworkers, Dr. Motoji Kawasak1, Mr. Mitsuhiko Shionoya, Mr. Hisaaki Chak1, and Mr. Kenj1 Ohta for their enthusiastic contribution. Partial financial support from the Science and Technology Agency, Japan, is gratefully acknowledged.

\section{REFERENCES}

1) For example, a) Cyclodextrins: M. Komiyama and M. L. Bender, in The Chemlstry of Enzyme Action, ed, by M. I. Page, Elsevier, Amsterdam, 1984, Chapter 14. b) Crown ethers: J. F. Stoddart, ib1d., Chapter 15, c) Cyclophanes: K. Odashima and K. Koga, in Cyclophanes, Vo1. 2, ed. by P. M. Keehn and S. M. Rosenfeld, Academlc Press, New York, 1983, Chapter 11. I. Sutherland, ibid., Chapter 12.

2) For example, a) R. Breslow and P. Campbell, J. Am. Chem. Soc., 91, 3085 (1969). b) Y. Murakam1, K. Aoyama, K. Dobashi, and M. Kida, BuIl. Chem. Soc. Jpn., 49, 3633 (1976). c) I. Tabush1, K. Yamamura, K. Fujita, and H. Kawakubo, J. Am. Chem. Soc., 101, 1019 (1979). d) F. Kotzyba-Hilbert, J. M. Lehn, and P. Viering, Tetrahedron Lett., 21, 741 (1980). e) D. C. Rideout and R. Breslow, J. Am. Chem. Soc., 102, 7816 (1980). f) G. L. Trainor and R. Breslow, 1bid., 103, $154(1 \overline{98} \overline{)}$ g) J. Winkler, E. Coutoul1-Argyropoulou, R. Leppkes, and R. Breslow, 1b1d., 105, 7198 (1983). h) I. Tabush1, Y. Kuroda, M. Yamada, H. Higashimura, and R. Breslow, 1 bid., 107, 5545 (1985).

3) W. P. Jencks, Catalysis in Chemistry and Enzymology, McGraw-Hill, New York, 1969, Chapter 2.

4) a) Y. Chao and D. J. Cram, J. Am. Chem. Soc., 98, 1015 (1976), b) Y. Chao, G. R. Weisman, G. D. Y. Sogah, and D. J. Cram, ibid., 101, 4948 (1979).

5) J. M. Lehn and C. Sirlin, J. Chem. Soc.,Chem. Commun., 1978, 949.

6) a) T. Matsui and K. Koga, Tetrahedron Lett., 1978,1115 . b) Idem, Chem. Pharm. Bu11., 27,2295 (1979). c) S. Sasak1, M. Kawasak1, and X. Koga, 1bid., 33, $4247(1985)$.

7) S. Sasak1, M. Shionoya, and K. Koga, J. Am. Chem. Soc., 107, 3371 (1985).

8) S. Sasaki, M. Shionoya, H. Chak1, K. Ohta, and K. Koga, unpublished data.

9) S. Yamada, Y. Yokoyama, and T. Sh101r1, Experientia, 32, 967 (1976). 